\title{
Group dynamics and interplay in UN disarmament forums: In search of consensus
}

Megan Dee, University of Warwick

The elimination of nuclear weapons has been an UN objective since 1946. Though addressed through multiple forums, including the UNGA First Committee, Conference on Disarmament, and the Nuclear Non-Proliferation Treaty, the possession and renunciation of nuclear weapons nevertheless remains a topic beset by multilateral stalemate and frustration over the entrenchment of positions between nuclear- and non-nuclear weapon states. And yet, within these forums, disarmament politics is taking a new turn with the emergence of new, crossregional, cross-factional political groups working alongside more established blocs. Focusing on these group dynamics, this article argues that the emergence of new political groups, and their interplay with others, is critical to the effective functioning of disarmament negotiations moving forward. Through means of cooperative information exchange, encouraging policy-entrepreneurship, and by challenging the rigidity of entrenched bloc positioning, these new group dynamics may make an important contribution in the search for consensus within the UN.

Keywords: UN; nuclear disarmament; group politics; multilateralism; NPT; consensusbuilding

\section{Introduction}

"When states parties to a treaty like the NPT meet to deliberate its future-and when they are obliged to reach decisions about the future of that treaty under the pressure of time-the importance of group dynamics becomes all the more apparent and undeniable."

\section{Jayantha Dhanapala President of the 1995 NPT Review and Extension Conference ${ }^{1}$}

In 1946 the very first resolution passed by the UN General Assembly (UNGA) established a Commission to deal with problems related to the discovery of atomic energy and to make proposals for, 'the elimination from national armaments of atomic weapons and of all other major weapons adaptable to mass destruction'. ${ }^{2}$ Today, the possession and renunciation of nuclear weapons continues to present a central topic of consideration for the UN, being addressed through multiple forums including the UNGA First Committee, the UN

\footnotetext{
${ }^{1}$ Jayantha Dhanapala \& Randy Rydell, Multilateral Diplomacy and the NPT: An Insider's Account (UN Institute for Disarmament Research, 2005), p.30

${ }^{2}$ UN General Assembly, 'Establishment of a Commission to Deal with the Problems Raised by the Discovery of Atomic Energy' A/RES/1(I) (1946)
} 
Disarmament Commission (UNDC), the Conference on Disarmament (CD), and the Nuclear Non-Proliferation Treaty (NPT) with its quinquennial review conferences (RevCon). ${ }^{3}$

Whilst a seemingly impressive institutional response by the UN in providing multiple forums for its members to debate and negotiate a world free of nuclear weapons, what these numerous forums also showcase is that, since 1946, the UN has had its hands tied in terms of achieving nuclear disarmament, requiring it to seek an agreement through various treatybased and organisational structures, none of which have been effective in providing a multilateral solution. These forums are beset by numerous challenges, not least that UN disarmament politics has been characterised by a fundamental divide between the world's nuclear 'haves' - namely the five UN-recognised nuclear weapon states (NWS) - and 'have-nots', the non-nuclear weapon states (NNWS). ${ }^{4}$ Work has thus been marred by multilateral stalemate, increasing frustrations, and heightened uncertainty. ${ }^{5}$

Within these forums however, a new dynamic is starting to emerge. As Jayantha Dhanapala highlights in the introductory quote to this article, the importance of group dynamics within forums like the NPT are both increasingly apparent and undeniable. Within UN disarmament negotiations individual state preferences, whilst regularly vocalised through formal statements or the submission of working papers, have since the late 1990s and early 2000s been far more frequently represented by a handful of prominent political groups, most notably including the Permanent-Five (P-5), the Non-Aligned Movement (NAM), the New Agenda Coalition (NAC), and a number of other important, if perhaps less high-profile, political groupings such as the European Union (EU) ${ }^{6}$ and the League of Arab States. Since

\footnotetext{
${ }^{3}$ In October 2012 the UNGA also established an Open-Ended Working Group (OEWG) on Taking Forward Multilateral Nuclear Disarmament Negotiations. This was a largely ad hoc body that met between March and April 2013 and then reported to the UNGA and CD. A further OEWG was announced following the conclusion of the $70^{\text {th }}$ session of the UNGA First Committee in October 2015, see UN Resolution 'Taking forward multilateral nuclear disarmament negotiations', A/C.1/70/L.13/Rev.1, 29 October 2015. Space constraints sadly prevent discussion of these OEWG, as well as other ad hoc debates such as UNGA Special Sessions devoted to disarmament.

${ }^{4}$ Christian Mölling, 'The grand bargain in the NPT: challenges for the EU beyond 2010' in Jean Pascal Zanders (eds.) Nuclear Weapons After the 2010 NPT Review Conference, EU Institute for Security Studies, Chaillot Papers (2010), pp. 49-70

${ }^{5}$ For example, see Reaching Critical Will, First Committee Briefing Book, (New York), 2015, p.4; UN News Centre, 'Consensus Eludes Nuclear Non-Proliferation Treaty Review Conference as Positions Harden on Ways to Free Middle East of Mass Destruction Weapons', 22 May 2015; UN News Centre, 'General Assembly President encourages disarmament meeting to stay focused', 3 March 2014

${ }^{6}$ Whilst the P-5 and NAM have been active in UN disarmament negotiations prior to the 1990s, the EU first began to present a common position, particularly within the NPT, following the signing of the Treaty on European Union in 1992. The NAC was formed in 2000.
} 
2010, the importance of group dynamics within UN disarmament forums has become even more apparent. This upturn in group dynamics has emerged as a direct result of the creation of several new political groupings, including the Non-Proliferation and Disarmament Initiative (NPDI), made up of twelve middle-ground and umbrella NNWS, promoting bridge-building language between diverging nuclear interests, and the Group of Sixteen (G16), made up of sixteen NNWS promoting what has become known as the Humanitarian Impact of Nuclear Weapons (HINW) or 'Humanitarian Initiative'?

As this article shall argue, these new group dynamics, and their interplay with other established political groups, are indicative of a growing effort by states to overcome the stalemate of UN disarmament politics by searching for a new consensus within the global nuclear non-proliferation regime. Through cooperative group interplay these new groups have not only promoted better information exchange and the fostering of dialogue between more entrenched group positions, but have encouraged a proactive agenda through policyentrepreneurship; further challenging the rigidity and conservatism of established bloc formations.

To present this case, and in keeping with the analytical framework detailed in the introduction to this special issue on the Multilateral Politics of UN Diplomacy, this article focuses on two critical research questions: First, how do states explicitly interact through groups within UN disarmament forums? And second, what difference do these group dynamics and interplay make to consensus-building in the case of UN disarmament politics? This article draws on the literature on multilateral diplomacy and negotiation theory, and presents empirical research covering the period 2005 to 2015. It is presented in four main sections. Section one gives a brief introduction to the established groups within the UN's numerous disarmament forums, the challenges they face, and the contribution that multilateral diplomacy and negotiation theory can make to understanding group politics at play in these forums. In section two, attention turns to the new group dynamics that have emerged in these forums since 2010, with particular focus given to why and how these groups were formed and the tactics they have employed in the search for consensus within the specific context of the NPT 2010-2015 review cycle. Section three considers the

\footnotetext{
${ }^{7}$ B. Tertrais 'The "humanitarian dimension" of nuclear disarmament: a legitimate debate?' Fondation pour la Recerche Strategique, note no. 12. 2015
} 
influence of these new group dynamics and what this may mean for UN disarmament politics in the future. The fourth section concludes.

The empirical data presented in this article is drawn from documentary analysis of state and group statements and working papers, NGO commentary, and UN press releases, along with interview data obtained by the author during two rounds of fieldwork undertaken in Brussels, New York and Geneva, between March and June 2011, and November 2014 and June 2015. Thirty-five semi-structured elite interviews were conducted in total over this period. Face to face and telephone interviews were conducted with officials at the level of Ambassador, Deputy Ambassador, First Secretary or Counsellor, on a non-attributable basis, and with all interviewees having first-hand experience of working within one, several, or all of the UN's disarmament forums, including those able to speak to closed room negotiations which are otherwise undocumented. Interviews were sought from a representative sample of the complete regional and political spread of views held within UN disarmament negotiations, and, most pertinently, those states involved in one or more political group, including members of the newly formed NPDI and G16. As agreed all interviewees have their anonymity preserved.

\section{The UN's disarmament politics: processes and challenges}

In previous decades, states have worked predominantly through a number of formalised regional and political groups within UN disarmament negotiations. As defined in the introduction to this special issue, ${ }^{8}$ regional groups are those five 'official' UN blocs such as the Western European and Other Group (WEOG), from which states are appointed to preside over positions within the numerous disarmament forums. In addition to the loose coordination and membership of states within these official regional blocs, states have also long been active within other typically smaller, yet often far more prominent, political groupings. Within UN disarmament forums there are a number of active formal political groups representing the main bloc-formations of state preferences on the issue of nuclear disarmament. These include most notably the P-5 representing the collective views of the five UN-recognised NWS, the $\mathrm{NAM}^{9}$ representing over 100 non-Western, developing, NNWS seeking the immediate elimination of nuclear weapons by the P-5, the NAC

\footnotetext{
${ }^{8}$ Karen E. Smith \& Katie Laatikainen, 'The Multilateral Politics of UN Diplomacy: Introduction' (this volume)

${ }^{9}$ For an interesting study on the functioning and politics of the NAM as a political group see Gaukhar Mukhatzhanova \& William Potter Nuclear Politics and the Non-Aligned Movement (The Adelphi series, International Institute for Strategic Studies, 2012)
} 
representing six prominent NNWS middle powers strongly in favour of nuclear disarmament, ${ }^{10}$ and, with varying levels of proactivity, the $\mathrm{EU}^{11}$ and League of Arab States ${ }^{12}$ each representing the common regional positions of their members.

Important to recognise however, is that there is no one main forum for addressing the elimination of nuclear weapons by the UN. Instead the UN today is home to numerous venues for debate and negotiation centred upon the basic remit of nuclear disarmament, ${ }^{13}$ within which political groups loosely arrange themselves. Of particular relevance is the NPT which is widely recognised as the cornerstone of the global nuclear non-proliferation regime. The NPT was signed in 1968 and entered into force in 1970. Its objectives were threefold. First, it enshrined the commitment by the P-5 to "pursue negotiations in good faith on effective measures relating to cessation of the nuclear arms race at an early date and to nuclear disarmament'. ${ }^{14}$ Second, it committed its majority NNWS to abstain from obtaining nuclear weapons or weapons technology and to accept safeguard and verification measures as set forth by the International Atomic Energy Agency. And third, it established the commitment by all states parties to ensure the peaceful uses of nuclear energy. Now with 190 states parties, the NPT today not only commits a total 185 states to the objective of nuclear non-proliferation, but is also the only international treaty in which the P-5 commit to the goal of general and complete nuclear disarmament.

The NPT is reviewed every five years in quinquennial review cycles including three Preparatory Committees (PrepCom) - held between New York and Geneva over three consecutive years, and culminating in a fifth year Review Conference (RevCon) which is held in New York over four weeks from April to May. NPT RevCons have a dual purpose: to review the previous five years of the Treaty's operation to consider its implementation and oversight, and to address the Treaty's forward momentum in agreeing points of action for the fulfilment of all states' obligations under the Treaty.

\footnotetext{
${ }^{10}$ Formed in 2000 and now comprised of Brazil, Egypt, Ireland, Mexico, New Zealand and South Africa.

${ }^{11}$ For an overview see Megan Dee, 'The EU's performance in the NPT review negotiations: Consistency, Change, Challenges' in D. Bourantonis, S. Blavoukos and C. Portela (eds.) The EU and the Non-Proliferation of Nuclear Weapons: Strategies, Policies, Actions. (Palgrave Macmillan: London, 2015)

12 The League of Arab States tends to have a variable presence in these forums but is a prominent group when it comes to discussions over the proposed Middle East WMD Free Zone

${ }^{13}$ Space constraints prevent discussion of other UN arms control forums which seek to limit the spread, or total elimination, of other weapons of mass destruction including biological, chemical weapons, missiles, and conventional arms, see: 〈http://www.un.org/disarmament/HomePage/Issues/>.

${ }^{14}$ UNODA, Treaty on the Non-Proliferation of Nuclear Weapons, 1968 (Art. VI)
} 
The NPT RevCon is however a treaty-based negotiating forum underwritten by a Grand Bargain: the vast majority of its signatories commit not to develop nuclear weapons, provided that the P-5 take practical steps towards the general and complete disarmament of their own recognised nuclear weapons programmes. ${ }^{15}$ A general contention nevertheless pervades NPT negotiations. Whilst the Grand Bargain implies equity across each of the NPT's three pillars, ${ }^{16}$ there is a marked imbalance in the NPT's negotiations which places far greater emphasis upon NNWS upholding their commitment to nuclear non-proliferation, than upon the NWS and their obligation to disarm. An underlying discrimination and inequality is therefore understood to exist between the nuclear and non-nuclear weapon states, ${ }^{17}$ most commonly centred upon the frustrations of NNWS over perceived failures of the P-5 to live up to their obligations to implement past RevCon decisions, ${ }^{18}$ or to take steps towards their nuclear disarmament.

Further supplementing the work of the NPT, and mirroring many of the same inherent challenges, is the UNGA First Committee. Meeting in session for four weeks every October to November, the First Committee considers and adopts resolutions and decisions on a range of issues from nuclear and other weapons of mass destruction to conventional arms, regional measures and disarmament machinery. Unlike the NPT, which makes decisions by consensus, the First Committee makes decisions based on one member, one vote, with voting often divided along 'official' UN group lines; although the P-5, NAM and NAC remain active as political groups within this forum. Whilst the First Committee does offer the NNWS some notable advantages due to sheer weight of numbers relative to the NWS, it is noted that consensus is also regularly sought for many resolutions adopted, particularly when they relate to the progress of multilateral disarmament negotiations. ${ }^{19}$ The First

\footnotetext{
${ }^{15}$ Mölling, 'The grand bargain in the NPT'

${ }^{16}$ Mölling 'The grand bargain in the NPT', p.49

17 Harold Müller 'A treaty in troubled waters: Reflections on the failed NPT review conference', The International Spectator, 40(3), 33 - 44, 2005, p.38, J. Ruzicka and N. Wheeler, 'The puzzle of trusting relationships in the nuclear non-proliferation treaty'. International Affairs, 86(1), 69-85. 2010, p.75

18 Reaching Critical Will, The NPT Action Plan Monitoring Report, March 2015; Megan Dee, 'The EU's multilateralist combat against the proliferation of WMD in the NPT: mirroring the Grand Bargain', European Security, 24(1), 1-20, 2015.

19 i.e. UN Resolution, 'Revitalising the work of the Conference on Disarmament and taking forward multilateral disarmament negotiations', A/C.1/66/L.39. 2011
} 
Committee has often been criticised for its failure to make any substantive progress and, thus, of contributing to the dysfunction of UN multilateral disarmament efforts. ${ }^{20}$

The First Committee works in close collaboration with the UN Disarmament Commission (UNDC), established in 1952. The UNDC is a subsidiary body of the UNGA and is composed of all UNGA members. It was created as a largely deliberative body with the purpose of considering and making recommendations on issues in the field of disarmament. Whilst the UNDC has in past years formulated consensus-based principles and recommendations for the First Committee, over the last decade it also has not agreed any substantive outcome. ${ }^{21}$

Further working alongside the NPT, First Committee, and UNDC is the Conference on Disarmament (CD). The CD was established in 1979 as the world's only permanent multilateral disarmament treaty negotiating body. Based in Geneva, the CD differs from the UNDC in that it is intended as a negotiation, rather than debating and advisory, forum. It also differs from the First Committee in that its focus is explicitly on the cessation of the nuclear arms race and nuclear disarmament as opposed to the First Committee's broader remit of international security and disarmament. Furthermore, in contrast to the NPT, the CD includes India, Pakistan, Israel and the DPRK amongst its sixty-five members. Its negotiation remit thus spans not only the objective of nuclear disarmament amongst the P-5, but crucially also those non-NPT states parties who possess nuclear weapons but who go unrecognised by the UN Security Council.

The CD differs moreover from the UN's other disarmament forums in that, whilst the P-5, $\mathrm{NAC}$, and EU do loosely coordinate in preparation for CD sessions, ${ }^{22} \mathrm{CD}$ members form into four main regional groups for the purposes of negotiations: the Western Group, the (NAM) Group of 21, the Eastern European Group, and the Group of One (China). In further contrast to the First Committee and UNDC, the CD meets in annual session, divided into three parts, meeting for ten weeks from January, seven weeks from May, and seven weeks from July. Despite having more time for negotiations, the CD nevertheless mirrors the NPT

\footnotetext{
${ }^{20}$ UN Meetings Coverage, 'Anxiety over Nuclear Weapons 'Deep and Genuine', 8 October 2015; Benjamin Seel, 'Frustration Evident in UN First Committee' Arms Control

Today, 2 December 2011

${ }^{21}$ UN Meetings Coverage, 'Disarmament Commission, Concluding 2015 Session, Urged Not to Lose Faith', 24 April 2015

${ }^{22}$ Interviews, June 2015
} 
in that it too faces the challenge of decision-making on the basis of the consensus rule whereby all sixty-five members must consent before a decision may be adopted. The CD has subsequently been hamstrung for the past two decades, rarely able to negotiate a substantive work programme, let alone a genuine consensus-based disarmament agreement. $^{23}$

As this discussion has demonstrated, multilateral stalemate besets the UN's numerous disarmament forums. Negotiators must manoeuvre not only intense power politics between the NWS, but also between an increasingly frustrated majority of NNWS who in turn align with various political groups reflecting a diverse mixture of geographical, political, and security-related preference-formations. From the perspective of multilateral diplomacy literature and negotiation theory therefore, UN disarmament politics is best characterised as an asymmetrical negotiation context, ${ }^{24}$ whereby the power symmetry of negotiations is balanced significantly in the favour of the P-5 who are ultimately responsible for deciding when, and how, they will relinquish their nuclear arsenals. As a consequence of the consensus rule within the UN's main negotiation forums - the CD and the NPT, as well as with most decisions of import to multilateral progress within the First Committee - the P-5 have been able to consistently present a conservative or status quo position, whereby they commit to the general objective of nuclear disarmament, but resist attempts by the UN to apply timetables, deadlines or binding imperatives. ${ }^{25}$

This does not however mean that NNWS political groups seeking a more progressive negotiation agenda are without resources to pursue their objectives over the course of the UN's disarmament negotiations. As negotiation theorists suggest, there are three main stages of multilateral negotiation including: (i) agenda-setting (ii) negotiation for formula and (iii) endgame bargaining. ${ }^{26}$ During the first phase stage, framing and argumentation may be employed in generating what Anatol Rapoport highlights as true debate, leading to consensus-building and collective action. ${ }^{27}$ Framing may, for example, be achieved through

\footnotetext{
${ }^{23}$ Kingston Reif, 'UN Disarmament Body Still Stalemated', Arms Control Today, 2 September 2015

${ }^{24}$ Ole Elgström \& M. Stromvik. 'The European Union as an international negotiator' in Elgström, O. \& Jönsson, C. (eds.) European Union Negotiations: Processes, Networks and Institutions (London: Routledge, 2005) p.121

${ }^{25}$ Interviews, May 2011; Interview, June 2015; Reaching Critical Will, The NPT Action Plan Monitoring Report

${ }^{26}$ Gunnar Sjöstedt, 'Leadership in Multilateral Negotiations: Crisis or Transition'p.233

27 See Smith \& Laatikainen, 'The Multilateral Politics of UN Diplomacy: Introduction'; Anatol Rapoport, Fights, Games and Debates (Ann Arbor: University of Michigan Press, 1960)
} 
the depoliticising of a contentious issue, focusing on technical rather than political or strategic details, or broader normative objectives that are considered more acceptable for deliberation. Argumentation may also be employed in stressing that an agenda is motivated by friendly intentions, or spelling out the positive details of what certain objectives might achieve. ${ }^{28}$ A particular agenda may also be pushed by linking an objective with legal or scientific principles in an effort to raise the level of concern amongst more conservative negotiation partners in support of more progressive objectives. ${ }^{29}$

More than this, during the negotiation for formula stage a party may undertake any number of tactics in an effort to enact change, even within an asymmetrical negotiation context. For example, a party's ability to come up with proposals that overcome differences is an important method by which a consensus-based agreement can be reached. New policy solutions or technical language, submitted through working papers or in statements, are an important provision of policy-entrepreneurship, and are critical in both persuading others to adapt their positioning and in providing language that might be utilised in endgame texts. ${ }^{30}$ More than this, as negotiation theory also indicates, in multilateral negotiations, coalitions are themselves considered important means of bringing the number of actors involved in negotiating often complex and politicised issues down to a more manageable number so that consensus can be more easily achieved. ${ }^{31}$ Where achieved moreover, coalitions within multilateral negotiations are seen as an important method of moving negotiations forward, or bringing them to a successful end. ${ }^{32}$ Within the context of the UN's disarmament forums therefore groups or coalitions of states are critical to understanding not only the stalemate that has beset negotiations, but also the potential to overcome this stalemate moving forward. The next section considers how such new groups form and pursue their objectives.

\footnotetext{
${ }^{28}$ Iklé, How Nations Negotiate p.197-2003

${ }^{29}$ Levy, M., Keohane, R. \& P. Haas, 'Improving the Effectiveness of International Environmental Institutions' in Haas, P., Keohane, R. \& M. Levy (eds.) Institutions for the Earth: Sources of Effective International Environmental Protection (MIT Press: Cambridge, MA, 2001) p. 399

${ }^{30}$ Zartman, I.W. \& Berman, M.R. The Practical Negotiator (Yale University, West Hanover, 1982), p.2; F.C. Iklé, How Nations Negotiate (New York: Frederick A. Praeger Inc. Publishers, 1964), p.193

${ }^{31}$ Ole Elgström \& Christian Jönsson, 'Introduction' in Elgström, O. \& Jonssön, C. (eds.) European Union Negotiations: Processes, Networks and Institutions (London: Routledge, 2005) p.2; V. Rittberger, 'Global Conference Diplomacy and International Policy-Making The Case of UN-sponsored World Conferences' European Journal of Political Research 11(2), (1983), pp. 167-182, p. 177

${ }^{32}$ Gunnar Sjöstedt, 'Leadership in Multilateral Negotiations: Crisis or Transition’ in Berton, P., Kimura, H., \& Zartman, I.W. (eds.) International negotiation: Actors, Structure/Process, Values (Hampshire, Macmillan Press Ltd, 1999) p.242
} 


\section{New group dynamics in UN disarmament forums}

Since 2010 multilateral disarmament negotiations within the UN have experienced a fundamental shift. The new decade began with a season of optimism for the global nuclear non-proliferation regime. In April 2010, the US published its Nuclear Posture Review setting out concrete steps to reduce its reliance on nuclear weapons and to move towards 'global zero'. ${ }^{33}$ In May 2010 the NPT RevCon further ended with a widely lauded 64-Point Action Plan detailing deliberate steps forward across all three pillars of the Treaty, including in nuclear disarmament. ${ }^{34}$ However, multilateral stalemate soon set in, ${ }^{35}$ and this time with growing frustrations being voiced, ${ }^{36}$ as it became apparent that several of the P-5 were not only resisting steps to enact the NPT Action Plan agreed in May, but were in some cases modernising existing arsenals. ${ }^{37}$

As a consequence of this resumption of stasis within the global non-proliferation regime, since 2010 a new dynamic has started to emerge centred upon a deliberate reframing of the nuclear debate away from the strategic and security-related discourses dominant since the Cold War, and onto humanitarian arguments for not only disarming, but outright banning, nuclear weapons. Following the same framing logics that have been successfully employed in the banning of landmines, cluster munitions, biological and chemical weapons, and which have been legitimised by their focus upon international humanitarian law, ${ }^{38}$ this new humanitarian discourse has sought to energise beleaguered NNWS, refocus the policy debate, and subsequently inject renewed momentum into multilateral disarmament negotiations. ${ }^{39}$

Of special interest is that this humanitarian discourse has largely resulted from the creation of a new political group active since 2010 both within the First Committee and the NPT's 2010-2015 review cycle. ${ }^{40}$ The Group of Sixteen was formed as an informal and ad hoc group of states parties and observers to the NPT shortly after the 2010 Action Plan was

\footnotetext{
${ }^{33}$ United States Department of Defence, Nuclear Posture Review 2010, 2010

34 UNODA, 'Final Document - Volume I' 2010 Review Conference of the Parties to the NPT (NPT/CONF/2010.50 (Vol. I)), 2010.

${ }^{35}$ Including further failures in the CD to adopt a programme of works in 2010

${ }^{36}$ Interviews, May-June 2011

${ }^{37}$ Reaching Critical Will, Assuring Destruction Forever: Nuclear Weapon Modernization Around the World, 2012

38 Interviews, June 2015; International Campaign Against Nuclear Weapons, Catastrophic Humanitarian Harm, 2012, p.23

${ }^{39}$ Interviews, June 2015

${ }^{40}$ Interview, June 2015
} 
introduced. Within the 2010 RevCon outcome document, states parties noted their deep concern over 'the catastrophic humanitarian consequences of any use of nuclear weapons' ${ }^{41}$ Recognising however, that more urgency was required to generate action towards nuclear disarmament by the 2015 NPT RevCon, and that a humanitarian consequences approach provided a comprehensive perspective from which to approach the problem, a new Group was formed. By the 2012 NPT PrepCom meeting in New York, the Group was presenting statements as the 'States Parties focusing on the Humanitarian Dimension', coordinated and led initially by Switzerland. ${ }^{42}$ From 2012 the 'Informal Group of Sixteen' began to undertake numerous proactive tactics to generate support for what had become widely known as the 'Humanitarian Initiative', including submitting working papers and hosting side-events at the NPT PrepComs in 2013 and 2014. Three of its members also hosted highprofile international conferences on the Humanitarian Impact of Nuclear Weapons (HINW) in Nayarit, Mexico in 2012, Oslo, Norway in 2013, and Vienna, Austria in 2014.

By the 2015 NPT RevCon the G16, backed by an impressive civil society campaign, had generated significant support for the Humanitarian Initiative, comprising a statement by Austria on behalf of 156 NPT states parties, ${ }^{43}$ and with growing numbers further signing or endorsing a 'Humanitarian Pledge'. ${ }^{44}$ This Pledge sets out the commitment by states parties 'to present the facts-based discussions, findings and compelling evidence of the Vienna Conference...to all relevant fora...in the UN framework'; and explicitly calls on all states parties to the NPT to, 'identify and pursue effective measures to fill the legal gap for the prohibition and elimination of nuclear weapons'. ${ }^{45}$ Whilst this campaign failed to achieve any timetable or agreed points of action at the 2015 NPT RevCon, the Humanitarian Pledge has nevertheless been considered the main outcome of that negotiation, ${ }^{46}$ and continues to

\footnotetext{
${ }^{41}$ UNODA, 'Final Document - Volume I', p.19

${ }^{42}$ UNODA 'Joint Statement on the humanitarian dimension of nuclear disarmament by Austria, Chile, Costa Rica, Denmark, Holy See, Egypt, Indonesia, Malaysia, Mexico, New Zealand, Nigeria, Norway, South Africa, Switzerland' Statement to the First Session of the PrepCom for the 2015 NPT RevCon, 2 May 2012

${ }^{43}$ UNODA 'Joint Statement on the Humanitarian Consequences of Nuclear Weapons' 28 April 015

${ }^{44}$ UNODA 'The Vienna Conference on the Humanitarian Impact of Nuclear Weapons and the Austrian Pledge' (NPT/CONF.2015/WP.29), 2015;See also

<http://www.bmeia.gv.at/fileadmin/user_upload/Zentrale/Aussenpolitik/Abruestung/HINW14/HINW14vienna Pledge Document.pdf $>$ which, at time of writing, had received 121 signatures

45 UNODA 'The Vienna Conference on the Humanitarian Impact of Nuclear Weapons and the Austrian Pledge'

${ }^{46}$ Ray Acheson, '2015 NPT Review Conference outcome is the Humanitarian Pledge' Reaching Critical Will, Negotiation Bulletin, 23 May 2015
} 
remain high on the UN's disarmament agenda, featuring particularly prominently in the UN First Committee's $70^{\text {th }}$ session from October-November 2015. ${ }^{47}$

A second new group to have formed since 2010 is the Non-Proliferation and Disarmament Initiative. Like the G16 the NPDI came into being shortly after the 2010 NPT RevCon with the deliberate intention of furthering the 64-Point Action Plan that had been agreed. ${ }^{48}$ Similar to the G16, the NPDI is an ad hoc group which has no formalised structure or secretariat. Coordination in both groups is conducted at senior official level and with each member state taking turns to represent collective group positions within the NPT's review cycle PrepComs, RevCon and in First Committee sessions. Like Switzerland in the case of the G16, the NPDI was an initiative led by Australia and Japan who sought the formation of a small yet focused group of like-minded states who could 'make a difference' in the proactive, yet 'pragmatic' furtherance of the 2010 Action Plan. ${ }^{49}$ As with the selection of members that formed the G16, the NPDI's membership was explicitly intended to be crossregional, including states of importance from regions around the world, and who were active both within the global nuclear disarmament debate and within other political groupings. ${ }^{50}$

For the NPDI, whose aim has been to provide what is considered a necessary bridge-builder role within the UN's disarmament forums ${ }^{51}$, and particularly the NPT, this includes various high-profile middle-ground States who have consistently adopted a pragmatic line in the nuclear disarmament debate such as Canada, Australia and Japan, as well, in many cases, as important regional players who themselves fall under a nuclear umbrella (for example as NATO members), and thus do not proactively seek the immediate abolition of nuclear weapons. In this way, such cross-regionalism, identifying key players to the debate but whose geographical location is also taken into consideration, has been seen to provide an important means of leverage for the NPDI, not least in being able to legitimately act in a mediatory role between the P-5 and the other established NNWS groups including the NAC and NAM. ${ }^{52}$

\footnotetext{
${ }^{47}$ UN Meetings Coverage, 'Frist Committee Sends 16 Drafts on Nuclear Disarmament to General Assembly, Including New One on 'Ethical Imperatives', Following 21 Recorded Votes', $70^{\text {th }}$ Session, $22^{\text {nd }}$ Meeting, 2 November 2015

${ }^{48}$ Interview, March 2015; Interview, June 2015

${ }^{49}$ Interview, June 2015.

${ }^{50}$ Interviews, March 2015; Interview, June 2015; Members of the NPDI include Australia, Canada, Chile, Germany, Japan, Mexico, the Netherlands, Nigeria, the Philippines, Poland, Turkey and United Arab Emirates

${ }^{51}$ Interview, June 2015

${ }^{52}$ Interview, June 2015
} 
Like the G16, the NPDI also adopted a proactive role within the NPT's 2010-2015 review cycle. It actively sought to contribute to the negotiations by building more cooperative relations with other groups and through the submission of carefully considered consensusbased policy language that could enable progress. ${ }^{53}$ The NPDI further demonstrated an impressive level of coordination as a new political group, ${ }^{54}$ not only internally whereby it has been able to share information between its own members, but also in its external coordination with other political groups including the P5 and NAC. ${ }^{55}$ This outreach to other groups, conducted through both formal meetings, and informally through the diplomatic relationships of NPDI members, was intended to ensure closer cooperation with the more established blocs and a freer exchange of views. ${ }^{56}$

As a result of this diplomatic coordination, the NPDI delivered numerous working papers to the NPT review negotiations, detailing consensus-based language, including proposals for taking forward action within the NPT. Prominent in this respect was one particular working paper which included a comprehensive and highly detailed summary of consensus-based language that might be adopted as final texts spanning all three of the NPT's main pillars. ${ }^{57}$ Recognised to reflect a middle-ground between the P-5 on the one hand, and the NAM and NAC on the other, this paper was subsequently reflected in the RevCon President's own draft summary report ${ }^{58}$ and which continues to be drawn upon in reflections for how the NPT may move forward into its next review cycle. ${ }^{59}$ The significance of the NPDI was moreover made clear when three of its members, Japan, Australia, and the Netherlands, were invited to join the 'small room' group of key negotiators hosted by the NPT RevCon President in order to finalise a consensus on nuclear disarmament in the final week of negotiations. $^{60}$

\footnotetext{
${ }^{53}$ Interview, June 2015

${ }^{54}$ Coordination was undertaken largely through regular email exchange as well as formal meetings prior to and on the side-lines of NPT PrepComs and the RevCon itself. During the 2015 RevCon NPDI members met formally once weekly to share information and fine-tune their language, as well as upwards of twice weekly through informal lunches (interview, June 2015)

55 Interviews, June 2015

${ }^{56}$ Interview, March 2015; Interview, June 2015

${ }^{57}$ UNODA, 'Recommendations for consideration by the 2015 Review Conference of the Parties to the NPT' Submitted by the NPDI (NPT/CONF.2015/WP.16), 2015

${ }^{58}$ Compare with UNODA, 'Draft Final Document - Part I' (NPT/CONF.2015/R.3), 2015

${ }^{59}$ Interviews, June 2015

60 This group was held at the Algerian Mission and also included all P-5 and NAC members, as well as Switzerland (G16 as well as Subsidiary Body 1 chair) Iran and Cuba (NAM), and Sweden (interviews, June 2015)
} 
As this discussion has demonstrated, in both the cases of the G16 and NPDI, significant efforts have been exerted to re-energise the UN's multilateral disarmament negotiations. For the G16 this has been apparent through their deliberate reframing of the nuclear debate to better account for the humanitarian impact of nuclear weapons. Utilising framing and argumentation tactics the G16 have presented an impressive case for a more progressive agenda within the UN's disarmament forums. Through reframing the debate in terms of the positive normative necessity of protecting human life, they have generated a significant body of support, not only amongst beleaguered NNWS who have lost faith that consensusbased decision-making can achieve results in these forums, but also amongst civil society which has bolstered the legitimacy and potency of the Humanitarian Initiative moving forward. ${ }^{61}$ For the NPDI, tactics have in contrast been geared less to reframing the nuclear debate and more to acting in a mediatory capacity between the P-5, NAC and NAM to generate momentum and push forward with multilateral solutions to the issue of nuclear disarmament. This has especially involved cooperative information exchange and subsequent policy-entrepreneurship with the submission of working language providing building blocks for incremental change.

In this way, both the G16 and NPDI have sought a path for progress and consensus within the UN's disarmament forums. ${ }^{62}$ Reflecting again upon Rapoport's analogy, in so doing these new group dynamics are indicative of efforts to overcome both the games of blocformation, entrenchment, and the conservatism of the P-5 in living up to their nuclear disarmament obligations, and to focus instead upon facilitating debate amongst NWS and NNWS in order to move closer to a consensus and, in time, collective action from the UN's disarmament forums. ${ }^{63}$ Whilst these efforts have, thus far, had little to show for themselves in terms of generating genuine action, they nevertheless suggest a glimmer of hope for UN disarmament politics. In the next section these positive signals and the influence that groups have had upon UN disarmament politics will be further developed.

\footnotetext{
${ }^{61}$ Interview, June 2015

${ }^{62}$ Interview, March 2015; Interview, June 2015

${ }^{63}$ Smith \& Laatikainen, 'The Multilateral Politics of UN Diplomacy: Introduction'; Anatol Rapoport, Fights, Games and Debates
} 


\section{The influence of groups in UN disarmament politics}

As the examples of the G16 and NPDI serve to highlight, groups within the UN's disarmament forums have influenced multilateral disarmament negotiations in three different ways. First, groups manage complexity by reducing the sheer number of voices, interests and perspectives at work within multilateral negotiations down to a more manageable number. This is particularly important within the NPT and First Committee where negotiations take place within a specified, and relatively tight, time-frame. As with the other established political groups at work in the UN's disarmament forum, including the P-5, NAC, and NAM, the G16 and NPDI were formed as coalitions of like-minded states in order to collectively pursue a broadly common position. By pursuing like-minded objectives through these groups, states have in turn been able to pool their (oftentimes scarce) resources and expertise whilst bolstering their own individual leverage. As the reality of UN disarmament negotiations is of an increasingly group-dominated form of multilateralism, working within groups is becoming a necessity for any state seeking to exert an influence within the negotiation process, not only in the pursuit of their own national agenda, but also in broader terms of supporting a multilateral consensus-based solution to achieve nuclear disarmament.

As the example of the G16 reveals, groups can also have a substantive influence through pooled social resources. In collaborating the member states of the G16 have become "norm entrepreneurs' capable of influencing debate through framing and argumentation, drawing upon wider normative principles - such as international humanitarian law - to enhance their legitimacy and to diffuse their group position to the wider NPT and First Committee communities. Closely related to this, groups influence UN multilateral disarmament negotiations courtesy of the enhanced diplomatic networks that they foster. As the example of the G16 and NPDI shows, members were deliberately sought out and invited to join not only based upon their geographical location, like-mindedness, and relative importance to the global nuclear disarmament debate, but also, in many cases, because those states also crucially aligned with other established political groups at work within the UN's disarmament forums. ${ }^{64}$

\footnotetext{
${ }^{64}$ Interviews, March 2015; Interviews, June 2015
} 
As Figure 1 demonstrates, all of the political groups at work within UN disarmament forums are closely interlinked with several examples of cross-alignment by states active in multiple groups. The G16 thus includes a cross-factional membership including most of the members of the NAC (Ireland, Mexico, South Africa, New Zealand and Egypt), key players of the NAM (Algeria, Chile, Indonesia, Malaysia, and the Philippines), the EU (Ireland, Denmark and Austria), and the NPDI (Mexico). The NPDI in turn comprises members of the EU (Germany, the Netherlands, and Poland) as well as the G16 (Mexico). The NAC is also notable for its cross-factional membership, including Ireland (a member of the EU and G16), South Africa and Egypt (NAM and G16), New Zealand (G16), and Mexico (G16 and NPDI).

Figure 1: Cross-alignment of major political groups within the NPT: 2010-

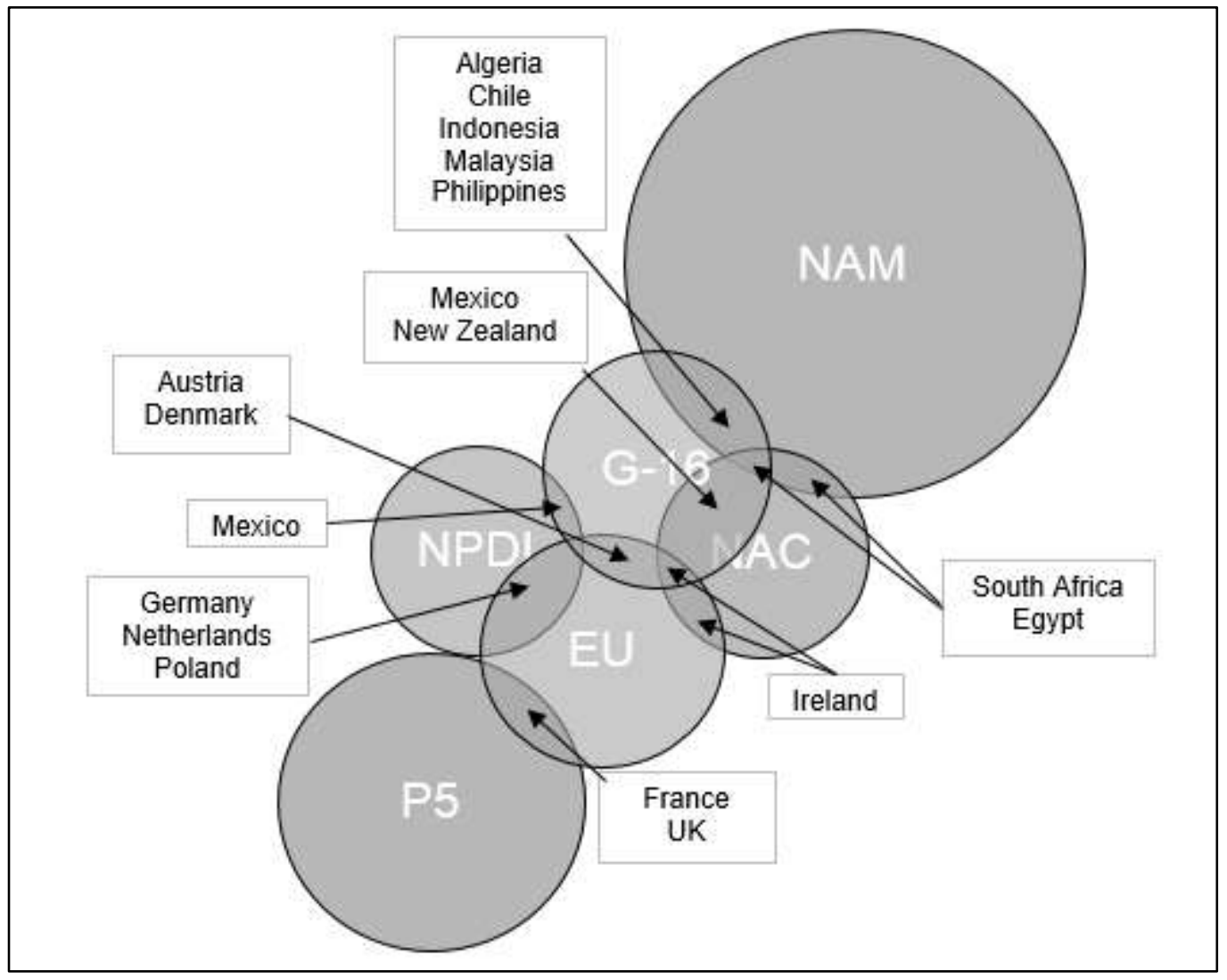

Source: Author's own compilation

Such cross-factional group memberships can have challenges. The inclusion of Mexico in the NPDI, for example, has generated some difficulties for the group in presenting bridgebuilding language that would appease Mexico (an ardent backer of a nuclear ban treaty), and 
still be conducive to the P-5. ${ }^{65}$ The EU has also frequently struggled to maintain its own unity of action within the NPT due to the cross-alignment of many of its more vocal member states within other political groupings. ${ }^{66}$ However, the benefits of group crossalignments within UN disarmament forums are also profound. Groups are considered by their members as crucial forums for information-sharing. Regular coordination between group members thus not only ensures a freer exchange of views and the pooling of intelligence, but also helps to build personal relationships, and even trust, between negotiators. ${ }^{67}$

When group members also align with other political groups, regular coordination further enables informal networks to be forged and closer intra-group exchanges fostered. This is an important influencing factor of group interplay because, through the active encouragement of cooperative exchanges, negotiators on opposing sides of a negotiation issue are far more likely to generate some 'zone of agreement' leading to possible consensus. ${ }^{68}$ Such intra-group cooperative exchange was apparent in the 2015 NPT RevCon through the activities of the NPDI, although the impact of this exchange may only become evident in the longer term. It has moreover been seen as a function of the EU in previous RevCons: the EU acting as an intelligence-sharing hub for those member states involved in other political groups during the 2010 RevCon, enabling the EU to contribute consensusbased language that formed part of the 2010 outcome document. ${ }^{69}$ As these examples suggest, whilst entrenched bloc positions and mistrust between negotiators can cause multilateral stalemate, cross-alignment of groups and more open diplomatic networks for information-exchange could be equally as important in overcoming it.

Finally, returning to the three stages of multilateral negotiation highlighted earlier, as this article has reflected, groups are found to have an influence within the UN's disarmament forums through the role that they play particularly during the agenda-setting and negotiation for formula stages. The work of the G16, for example, has fundamentally altered the agenda of the UN's disarmament forum since 2010. The increased focus on the humanitarian

\footnotetext{
${ }^{65}$ Interviews, June 2015

${ }^{66}$ Megan Dee 'The EU's performance in the NPT review negotiations: Consistency, change, challenges'

${ }^{67}$ Interview, November 2014; Interviews, June 2015

68 Arild Underdal, 'Causes of Negotiation 'failure"” European Journal of Political Research 11(2) (1983), 183-195

${ }^{69}$ Megan Dee, 'Standing together or Doing the Splits? Evaluating European Union Performance in the Nuclear non-Proliferation Treaty Review Negotiations' European Foreign Affairs Review, 2012, 17(2), 187-210
} 
consequences of nuclear weapons as a specific discourse within the NPT and First Committee can be seen as a direct consequence of this group's formation and activities in garnering support for the Humanitarian Initiative. The NPDI has moreover demonstrated an important influence over the negotiation for formula phase of the NPT's 2015 review negotiations through its efforts in policy-entrepreneurship; coming up with consensus-based middle-ground language that was then taken forward in the President's draft summary report. In this way, groups, and new groups especially, are starting to make a purposeful difference to the processes involved within the UN's disarmament forums.

What remains to be seen is the extent to which groups can make a direct influence upon endgame bargaining and thus the subsequent outcome of UN disarmament negotiations. The fact that the 2015 NPT RevCon failed to achieve a consensus-based final document, despite the efforts exerted by the G-16, NPDI and other group players such as P-5, NAC and NAM, would suggest limits to the influence that political groups can have within such a difficult negotiation environment. The ongoing stalemate of UN disarmament negotiations is not easily overcome, even with new group dynamics coming to the fore. And yet, the fact that it was key members of the P-5, NAC, NPDI and G-16 that came together in the final week of the 2015 NPT RevCon to seek agreement on draft texts is suggestive of groups having an important role to play in endgame bargaining. Whilst it is understood that states involved in such 'small room' endgame discussions do participate in their national capacity, it is also crucially their group participation that enables them to feed back to a wider membership, build consensus, and in turn ensure support for any negotiated outcome agreement. Time will therefore tell if these new group dynamics can make a difference in this way and, in turn, overcome the multilateral stalemate of UN disarmament forums.

\section{Conclusion}

In this article, group dynamics within the UN's disarmament forums have been considered. Two research questions are at its heart: first, how do states explicitly interact through groups in UN disarmament forums; and second, what difference do these group dynamics and interplay make to consensus-building? Focusing on the first research question, it has been shown that states are understood to interact within political groups within UN disarmament forums for the purposes of pooling knowledge and resources whilst further enhancing their leverage, legitimacy, and bargaining strength relative to other group players. As the example of the new G16 and NPDI groups reflect, memberships of political groups in disarmament 
forums is a careful calculation; taking into consideration not only like-mindedness, but importance of the state in the nuclear disarmament debate, geographical spread, and, importantly, the alignment of that state within other political groupings.

This, in turn, is important for understanding the difference that group dynamics and interplay make to consensus-building within disarmament negotiations. This article finds that the influence of group dynamics within the UN's disarmament forums is evident in three clear ways. First, the formation of political groups within UN disarmament forums manages the complexity of negotiations by reducing the number of interests, preferences and voices down to a more manageable number, thus enabling negotiators to concentrate on selected priority issues and to engage with others within the timeframe permitted to them. Second, the group dynamics at play within these forums, and particularly within the NPT, has since 2010 been notably more influential in fostering cooperative intra-group exchanges. By drawing upon the cross-alignment of their members with other political groupings and by acting as hubs for intelligence sharing, new groups have reflected an important means of consensus-building which could lead to improved diplomatic networks between entrenched group positions moving forward.

Finally, groups are influencing consensus-building within the UN's disarmament forums particularly through the agenda-setting and negotiation for formula stages of multilateral negotiation. As the new group dynamics of the G16 and NPDI represent, political groups and their interplay can make a substantive difference both to the underlying discourse and agenda of multilateral disarmament negotiations, and the processes by which consensusbased policy language can be formulated and taken through to decision-making. What will be revealing, and a topic ripe for future research, is how these groups will continue to not only shape negotiation processes, but in fact impact outcome through endgame bargaining. Whilst evidence would suggest that we cannot overstate this influence to date, the new group dynamics now at play are indicative of groups taking on an increasingly prominent and shaping role, not only in overcoming the entrenchment of more established blocs within the UN's disarmament forums, but, in time, of delivering consensus-based, negotiated outcome agreements that may pave the way to progress for the UN. 